INFORMACIÓN AL PACIENTE

Sección coordinada por:

V. F. Moreira y A. López San Román

Servicio de Gastroenterología. Hospital Universitario Ramón y Cajal. Madrid

\title{
Profilaxis de la hepatitis A
}

\section{¿QUÉ ES?}

La profilaxis de la hepatitis A incluye todas las medidas encaminadas a evitar la difusión de esta enfermedad, tanto en el aspecto general como en el individual. Es decir, se trata de impedir que el virus de la hepatitis A (VHA) contamine los alimentos y el agua de la bebida y que las personas que tengan contacto con el virus desarrollen la enfermedad.

\section{¿EN QUÉ CONSISTE?}

La profilaxis general incluye diversas medidas sanitarias. Ejemplos son la potabilización de las aguas de consumo mediante cloración, el tratamiento de los vertidos para evitar que las aguas residuales contaminen las potables, o la educación de los manipuladores de alimentos para que adopten una higiene escrupulosa durante el trabajo. La profilaxis individual consiste en la inmunización mediante gammaglobulina y vacuna. La administración de gammaglobulina proporciona anticuerpos contra el VHA y la de vacuna induce al receptor a fabricar tales anticuerpos.

\section{VENTAJAS E INCONVENIENTES DE LA GAMMAGLOBULINA Y DE LAS VACUNAS}

La gammaglobulina confiere una protección inmediata pero de breve duración (pocas semanas). La vacuna confiere una protección permanente (al menos durante 20 años) pero requiere de unas dos semanas para inducir un título de anticuerpos protector.

\section{¿EN QUIÉNES ESTÁ INDICADA LA PROFILAXIS?}

La gammaglobulina está indicada cuando se precisa un efecto inmediato, por ejemplo tras una exposición al virus (contacto cercano con un paciente) o cuando no se dispone de tiempo para esperar que la vacuna haga su efecto, como sucede en quienes van a viajar a países donde existe el riesgo de contraer hepatitis y deciden a última hora consultar acerca de qué hacer. La vacuna está indicada, según el Ministerio de Sanidad español, en las personas incluídas en los siguientes grupos de riesgo: cualquier viajero a regiones donde el VHA es muy común (Iberoamérica, Sudeste asiático, África), adictos a drogas por vía parenteral, homo y bisexuales masculinos promiscuos, hemofílicos, niños asistentes a guarderías y sus cuidadores, trabajadores de estaciones de depuración de aguas residuales o en alcantarillado, manipuladores de alimentos y personal sanitario de hospitales.

Cuando se identifica un brote epidémico de hepatitis A de carácter comunitario, la administración de gammaglobulina o de una dosis de vacuna puede contribuir a interrumpir el brote. A los contactos domésticos y sexuales de un paciente con hepatitis $\mathrm{A}$, debe administrarse lo más rápidamente posible una dosis de gammaglobulina inespecífica, preferible a la vacuna por su efecto inmediato.

\section{¿TIENE ALGÚN EFECTO ADVERSO?}

El único efecto adverso que presenta la vacuna es inflamación en el lugar de la inyección y en pocos casos (5\%) fiebre. La gammaglobulina no presenta ningún efecto adverso.

\section{¿CÓMO SE ADMINISTRA?}

La gammaglobulina se administra en una sóla dosis por vía intramuscular a dosis de $0,02 \mathrm{ml} / \mathrm{kg}$ de peso. La vacuna se administra en dos dosis separadas por un intervalo de 6 a 18 meses por vía intramuscular en el deltoides.

\section{¿DE QUÉ PREPARADOS DE VACUNA PODEMOS DISPONER?}

Existen varias vacunas inactivadas frente al VHA (HAVRIX, Glaxo Smith Kline, VAQTA Merck Sharp Dohme y AVAXIM Aventis Pasteur). Todas ofrecen igual seguridad y eficacia. Hay una vacuna combinada A+B (TWINRIX, Glaxo Smith Kline) para vacunar simultáneamente contra los virus de la hepatitis A y B.

\section{¿CUÁL ES SU EFICACIA?}

La vacuna de la hepatitis A da lugar a una inmunidad protectora (anti VHA) en el $100 \%$ de los vacunados. Su eficacia es muy alta siempre que el contacto con el virus no se haya producido antes de que se hayan formado los anticuerpos.

La gammaglobulina es igualmente protectora en el $85 \%$ de los casos, pero es ineficaz si se administra 14 días o más después del contacto.

\section{¿ESTÁ JUSTIFICADA LA VACUNACIÓN UNIVERSAL?}

Sería la medida más eficaz para combatir la hepatitis A, pero no se ha impuesto de modo general porque se considera que el coste sería excesivo, teniendo en cuenta que la hepatitis A no se cronifica. En Cataluña existe un programa de vacunación universal en adolescentes (12 años) con vacuna combinada $\mathrm{A}+\mathrm{B}$.

\section{¿HAY QUE EXAMINAR LOS CANDIDATOS A LA VACUNA DE LA HEPATITIS A ANTES DE LA VACUNACIÓN?}

En los casos de vacunación no urgente, se recomienda comprobar previamente en los mayores de 30 años si tienen anticuerpos (IgG) anti VHA; de este modo recibirían la vacuna únicamente las personas susceptibles, que son aquellas que no los poseen. En los menores de 30 años se puede vacunar directamente. 